\title{
Physical Performance Enhancing Effects of The Aqueous Extract of Alysicarpus Ovalifolius in Mice
}

*Lucy Binda JOHN-AFRICA', Lovelyn KesiennaELOUR', Samuel Ehiabhi OKHALE², Bulus ADZU1

1 Department of Pharmacology and Toxicology

2Department of Medicinal Plants Research and Traditional Medicine

National Institute for Pharmaceutical Research and Development, P.M.B. 21 Garki, Idu Industrial Area, Abuja, Nigeria.

\begin{abstract}
Alysicarpus ovalifolius (fabaceae) is an herb used as ingredient of tea that is consumed as a tonic in Northern Nigeria. This study evaluated effects of aqueous extract of the aerial parts of Alysicarpus ovalifolius (AO) on physical performance in Swiss albino mice. Phytoconstituents were identified by HPLC. Performance was assessed by exhaustive swim, rotarod, four limb-hanging and hypoxia test. Effects on diazepam-induced sleep was also evaluated. HPLC detected presence of caffeic (60.34\%) and chlorogenic acids (3.44\%) and rutin (0.19\%). The extract (100 $-400 \mathrm{mg} / \mathrm{kg}$ ) produced significant $(\mathrm{p}<0.05$ ) dose-dependent increase in swimming time; increased time spent on the rotarod and also increased duration in the fourlimb hanging test. No significant effect was observed in endurance to hypoxic condition. Diazepam-induced sleeping time was significantly decreased in AO-treated animals. These observations were comparable to caffeine $(15 \mathrm{mg} / \mathrm{kg})$. The aqueous extract of Alysicarpus ovalifolius increased physical performance in mice by enhancing endurance, muscle strength and co-ordination.
\end{abstract}

Keywords: Alysicarpus ovalifolius, endurance, swim, muscle strength

\section{INTRODUCTION}

Psychotropic drugs have been defined as substances used mainly to relieve

Corresponding author: Lucy Binda JOHN-AFRICA

Email: Ibjafrica@yahoo.com

Telephone: +2348058577557

ORCIDs:

Lucy Binda JOHN-AFRICA: 0000-0002-2771-0526

Samuel Ehiabhi OKHALE: 0000-0002-9931-3618

Bulus ADZU: 0000-0001-6201-9100

(Received 18 August 2020, accepted 29 March 2021) 
symptoms of mental or emotional origin without impairing consciousness ${ }^{1}$ and psychoactive stimulants are psychotropic substances that can stimulate the central nervous system to cause excitation, increased alertness and elevated moods ${ }^{2}$. They are used clinically for the management of neurological conditions ${ }^{1}$. These agents are used in clinical settings for the management of mood and attention disorders such as depression and attention deficit hyperactivity disorders (ADHD), as well as for relieve of nasal congestion and also in orthostatic hypotension and postural orthostatic tachycardia syndrome ${ }^{3,4,5}$.

The use of these substance in healthy individuals is an increasingly alarming global phenomenon. An earlier study showed the category of users cutting across the different strata of society ${ }^{6}$. Stimulant use has been reported globally amongst students as well as the adult population irrespective of gender, educational, financial or employment status $\mathbf{s}^{7,8,9,10}$.

Non-medical reasons that have been given for use of psychoactive stimulants by healthy individuals include enhanced physical and mental alertness, improved memory and attention, increased sociability, euphoria, increased arousal, to loosen inhibitions, improve moods, motivation, relief of pain, inhibition of fatigue thus improving endurance and productivity. They have also been applied to cosmetics and for weight loss due to the ability to suppress appetite. These effects have been demonstrated in studies involving animal and human subjects ${ }^{2,11,12,13}$. As a result of these attributes of the CNS stimulants, there is high propensity for misuse of these substances for recreational purposes with resultant deleterious effects on the normal functions on the individuals that use them. Identified harmful effects may include headache, decreased appetite, psychological and physical dependence and addiction ${ }^{9,14,15}$.

A wide range of substances can be included in this category ranging from substances with mild effects such as caffeine in coffee and energy drinks, methylxanthines as occurring in tea, nicotine which is present in tobacco and kolanut; to prescription analgesics and other substances like cocaine and amphetamines that have profound activities on the physiological processes of the organism ${ }^{10}$.

Many plants containing phytochemical compounds have been reported to have stimulant effects and have been demonstrated to improve stamina ${ }^{5}$. 'Gadagi' is a type of herbal tea made using Alysicarpus ovalifolius alone or in combination with other plant parts. This is consumed by persons engaged in labour demanding activities to improve alertness, cognition and gain strength for enhanced performance especially at physically demanding tasks ${ }^{16}$. 
Alysicarpus ovalifolius (Schumach. \& Thonn.) J. Leónard is an annual herb that is wide spread in West and East Africa as well as Asia and the United States. The weed is a protein-rich fodder for live-stock and has been reportedly used as wound medicine ${ }^{17}$ (t'mannetje, 2002). The CNS stimulant action for this plant has been reported ${ }^{18}$ as well as its use as stimulant for child birth ${ }^{19}$. This study was designed to evaluate the effects of the aqueous extract of Alysicarpus ovalifolius on physical performance and endurance using mice.

\section{METHODOLOGY}

\section{Plant material}

The aerial parts of Alysicarpus ovalifolius were collected from Suleja, Niger State, Nigeria, in the month of August 2017 by Mal Ibrahim Muazzam. The plant was identified and authenticated by the curator of the Department of Medicinal Plant Research and Traditional Medicine, National Institute for Pharmaceutical Research and Development (NIPRD) Idu, Abuja, Nigeria, where a voucher specimen (NIPRD/H/6920) was prepared and deposited for future reference.

\section{Collection and extract preparation}

The aerial parts of the plant were collected by cutting with a pair of scissors about $2 \mathrm{~cm}$ off the ground. Sand particles and other debris were shaken off. The plant material was then washed and air-dried under a shade until a constant weight was obtained. This was further cut with a pair of scissors and subsequently pulverized using a pestle and mortar to obtain a coarse material.

A decoction of the plant material was prepared by boiling one hundred and fifty grams $(150 \mathrm{~g})$ of the crushed plant material in water for $20 \mathrm{~min}$. This was then allowed to cool overnight after which it was filtered using a muslin cloth and the marc pressed to strain out as much liquid as possible. The filtrate was further filtered using a Whatman filter paper No 1 . This was then evaporated to dryness on a water bath to afford a dark-brown solid (the extract) with a yield of $11.65 \%$ $\mathrm{w} / \mathrm{w}$ and stored in a refrigerator in an air-tight container.

\section{Phytochemical Test}

\section{High Performance Liquid Chromatography (HPLC) Analysis}

The bioactive constituents of the extract were analyzed by high performance liquid chromatography. The HPLC consisted of Ultra-Fast LC-2OAB equipped with SIL-20AC auto-sampler; DGU-20A3 degasser; SPD-M2OA UV-diode array detector; column oven CTO-20AC, system controller CBM-20Alite and Windows LC solution software (Shimadzu Corporation, Kyoto Japan); column, $5 \mu \mathrm{m}$ VP-ODS C18 and dimensions ( $4.6 \times 150 \mathrm{~mm})$. The chromatographic con- 
ditions included mobile phase: $0.2 \% \mathrm{v} / \mathrm{v}$ formic acid and acetonitrile (20:80); isocratic mode; flow rate $0.6 \mathrm{ml} / \mathrm{min}$; injection volume $10 \mu \mathrm{l}$ of $50 \mathrm{mg} / \mathrm{ml} \mathrm{solu-}$ tion extract in the mobile phase; detection UV $254 \mathrm{~nm}$. Reference standards rutin, caffeic acid, ferulic acid and chlorogenic acid respectively were analyzed under the same condition as the extract. The HPLC operating conditions were programmed to give the following: solvent A: $80 \%$, solvent B: $20 \%$, column oven temperature was $40{ }^{\circ} \mathrm{C}$ and total run time of 20 minutes $^{20}$.

\section{Animals}

Swiss male albino mice (25 - 29 g), obtained from the Animal Facility Centre (AFC) of the National Institute for Pharmaceutical Research and Development, Abuja, Nigeria were used for the studies. All animals were housed under ambient conditions and fed on standard rodent diet and clean drinking water ad libitum. Animals were approved for this study based on the experimental and animal handling conditions which were in compliance with the ethical requirements of the Institutional Animal Care and Ethics (ACE) Committee (NIPRD/05.03.05-08).

\section{Swim Test}

Mice were weighed and randomly placed into five groups of 6 mice each. Group 1 was administered distilled water (negative control), group 2 served as the positive control and received caffeine $15 \mathrm{mg} / \mathrm{kg}$ (standard drug), while groups $3-5$ test groups were given graded doses of the extract at 100, 200 and $400 \mathrm{mg} /$ $\mathrm{kg}$ (respectively). Extract/drug were administered orally by means of an orogastric cannula. Plastic containers with measurements of $32 \times 50 \times 35 \mathrm{~cm}$ were filled with water maintained at temperature of $33 \pm 1^{\circ} \mathrm{C}$ to a marked level of a depth of $25 \mathrm{~cm}$. Sixty minutes after treatment a weight equivalent to $10 \%$ of the body weight was attached to the tail of each mouse. The mice were then placed individually into the water with a stopwatch started simultaneously. The mice were allowed to swim to exhaustion (when the animals sank below the level of the water and could not come back up within $7 \mathrm{sec}$ ) after which the mice were removed, toweled and placed under a lamb to dry ${ }^{21}$.

\section{Rota-rod test}

A rotarod device (Ugo Basile, 7560, Milano, Italy) was used for this study. Mice were pre-trained to remain on moving rods of $3 \mathrm{~cm}$ diameter. Mice that fell off the rod were immediately placed back on the rod. However, animals that fell up to three times during the trial period were removed. The animals were subsequently grouped into five groups $(\mathrm{n}=6)$ and treated with distilled water, caffeine $15 \mathrm{mg} / \mathrm{kg}$ (o.p) or extract (100, 200 and $400 \mathrm{mg} / \mathrm{kg}$ ). Sixty minutes 
post-treatment, animals were simultaneously placed in separate lanes on the stationary rod. The motor was then turned on and the rod allowed to accelerate up to $20 \mathrm{rpm}$ and held at that rate. The mice were allowed to remain until they fell off the rotating bars. Tests began when acceleration was started and ended when an animal fell off the rod. The procedure was repeated three times at 15min interval. The latency to fall was recorded. Endurance was interpreted as increased duration of stay on the $\operatorname{rotarod}^{22,23}$.

\section{Four-limb hanging test}

Treated mice were individually made to hang on all four limbs from the underside of a wire mesh such that the limb tension opposed their body weight. The mesh was held at a height of $30 \mathrm{~cm}$ and the table top lined with soft padding so as to cushion any mouse that fell off the grid. The timer was started when the mice held onto the mesh and stopped when the animals fell off or reached a maximum holding time of $20 \mathrm{~min}$. Test was repeated three times for each mouse with an interval of $2 \mathrm{~min}^{24}$. Prior to the test, mice were trained to hang on the wire mesh. Mice that fell off were immediately placed back on the wire. Animals that fell up to three times during the trial period or jumped off were removed from the study.

\section{Hypoxia Endurance test}

Treated mice were placed individually in airtight containers with capacity of $300 \mathrm{ml}$. A timer was started immediately and then stopped at the onset of convulsion in the mice. The animals were subsequently exposed to air and allowed to recover. The latency to onset of convulsion was taken as the endurance to hypoxia ${ }^{25}$.

\section{Diazepam induced sleeping time}

The test subjects were randomly placed into 5 groups of 7 animals each. The mice were treated with distilled water, caffeine $15 \mathrm{mg} / \mathrm{kg}$ (o.p) or extract (100, 200 and $400 \mathrm{mg} / \mathrm{kg}$ ). Sixty min later, each animal received diazepam $25 \mathrm{mg} /$ $\mathrm{kg}$ (i.p.). The time taken for loss of the righting reflex indicated the onset of sleep, while the time between the loss and recovery of the righting reflex for each mouse was taken as the duration of sleep. The period of onset and duration of sleep were calculated for each mouse ${ }^{26}$.

\section{Statistical analysis}

Group data were presented as Mean \pm SEM. The data on exhaustive swim, diazepam induced sleep and hypoxia endurance tests were analyzed by one-way ANOVA followed by a post hoc Dunnet's test and two-way ANOVA followed by 
a post hoc Bonferroni test was used to compare the data in the rotarod and four limb hanging tests. Graphpad PRISM ${ }^{\circledR}$ 6.0 was used. The level for statistical significance was set at $\mathrm{p}<0.05$.

\section{RESULTS and DISCUSSION}

The study was designed to investigate the effects of the aqueous extract of the aerial part of Alysicapus ovalifolius (AO) on physical activity using mice which had been subjected to exercise and identify the bioactive compounds that may be involved in the activity. The HPLC chromatogram (Figure 1) showed that nine peaks were detected with retention times in minutes of $3.67,4.56,6.44$, $9.52,10.54,11.35,14.12,15.55$ and 16.60. Identification of the phytoconstituents of the extract was achieved by comparing their retention times with those of the reference standards analyzed under the same experimental condition as the extract. Compound with retention time of 3.67, 4.56 and 6.44 minutes corresponded to chlorogenic acid, caffeic acid and rutin (Figure 1) which was equivalent to $3.44 \%, 60.34 \%$ and $0.19 \%$ respectively of the contents of the extract.

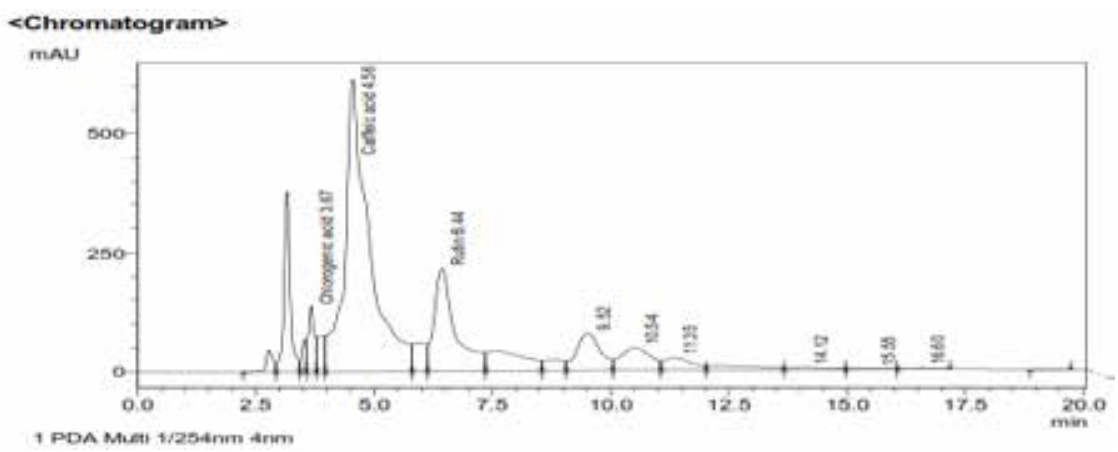

Figure 1: HPLC chromatogram of the aqueous extract of Alysicarpus ovalifolius (A0) extract with detection UV at $254 \mathrm{~nm}$ showing 9 peaks which include caffeic acid $(60 \%)$, chlorogenic acid $(3.44 \%)$ and rutin $(0.19 \%)$.

Swim endurance and rotarod animal models test for fatigue in animals ${ }^{27}$. Treated animals subjected to exhaustive swim test, demonstrated significant dosedependent increase in swimming time in all extract treated animals with 200 and $400 \mathrm{mg} / \mathrm{kg}$ exhibiting significant $(\mathrm{p}<0.05$ ) increase (Table 1). The swimming endurance test is an experimental exercise model that assesses exercise durabili$\mathrm{ty}^{28}$. Swim test when applied in laboratory animals directly measures fatigue thus evaluating endurance capacity. Prolonged swimming time connotes reduced susceptibility to fatigue and enhanced endurance ${ }^{29}$. The prolonged swim time exhibited by the extract suggests the extract's effect to delay the onset of exhaustion ${ }^{30}$. 
Table 1: Effect of aqueous extract of Alysicarpus ovalifolius (A0) on exhaustive swim test.

\begin{tabular}{lll}
\hline Treatment & Dose $(\mathbf{m g} / \mathbf{k g})$ & Duration of Swimming (min) \\
\hline Distilled water & $10 \mathrm{ml} / \mathrm{kg}$ & $35.75 \pm 16.87$ \\
Caffeine & 15 & $119.20 \pm 8.46^{\mathrm{a}}$ \\
A. ovalifolius & 100 & $91.75 \pm 24.30$ \\
A. ovalifolius & 200 & $110.00 \pm 19.65^{\mathrm{a}}$ \\
A. ovalifolius & 400 & $138.90 \pm 20.61^{\mathrm{b}}$ \\
\hline
\end{tabular}

Results are presented as mean $\pm \operatorname{SEM}(n=6) .{ }^{a} \mathrm{p}<0.05,{ }^{\mathrm{b}} \mathrm{p}<0.01$ significant difference between distilled water and treated groups.

In the rotarod test, all animals successfully completed 3 successive tests on the horizontal rotarod. Pre-treatment with the extract at 100 and $200 \mathrm{mg} / \mathrm{kg}$ prolonged the time animals stayed on the rotating rods, however time spent on the rods at $400 \mathrm{mg} / \mathrm{kg}$ group was observed to be lower compared to the 100 and $200 \mathrm{mg} / \mathrm{kg}$ groups. The increase in time spent on the rotating rod was significant $(\mathrm{p}<0.05)$ for the extract at 100 and $200 \mathrm{mg} / \mathrm{kg}$ and caffeine when compared to the distilled water group. The endurance period was highest in the 200 $\mathrm{mg} / \mathrm{kg}$ treated group (Figure 2).

This test has been used to assess balance and coordination in motor performance and endurance in rodents ${ }^{31}$. The accelerating rotarod eliminates the need for extensive training or the introduction of maximal time limit for performance $^{32}$. This model measures an animal's ability to maintain itself on a rod being turned at accelerating speed, thus it is used to test drugs that may interfere with skeletal muscle co-ordination and cause motor impairment ${ }^{33,34}$. Fatigue may impair muscle co-ordination thereby hampering performance at tasks that require motor skill ${ }^{30}$. The increase in the duration of the task performed by the mice on the rotarod may suggest an enhancement of motor co-ordination in animals after extract treatment or improvement of resistance to physical stress ${ }^{35}$. 


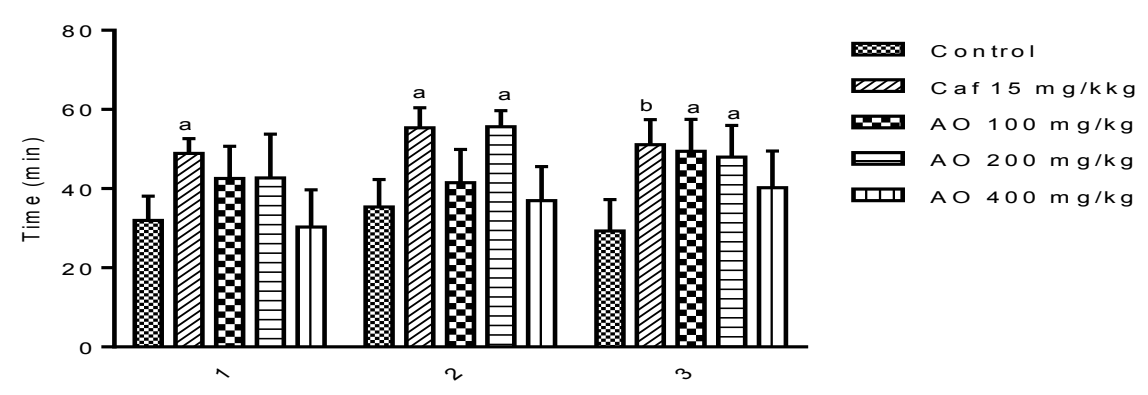

$\mathrm{DW}=$ Distilled water, $\mathrm{CAF}=$ Caffeine. Values are mean $\pm \operatorname{SEM}(\mathrm{n}=6) ;{ }^{\mathrm{a}} \mathrm{p}<0.05$, ${ }^{b} \mathrm{p}<0.01$ significant vs control (Two-way ANOVA followed by Dunnet's post hoc test).

Figure 2: Effect of aqueous extract of Alysicarpus ovalifolius (AO) on rotarod endurance test.

In the four-limb hanging test, all animals successfully completed all the trials. The period that the animals hung on the mesh was prolonged on administration of the extract and caffeine. The hanging time increased with successive tests in all treated animals. The observed increase was significant $(\mathrm{p}<0.05)$ for the extract and caffeine on comparison to the negative control group. The four-limb hang time increased with subsequent trials, with $200 \mathrm{mg} / \mathrm{kg}$ group exhibiting the longer duration on all three sessions (Figure 3). This test assesses muscle strength in all four limbs of the mice and can be applied to demonstrate neuromuscular impairment and the lack of coordination or to study the effects of genetic or pharmacologic treatments on skeletal muscle functionality ${ }^{24}$. In this test, administration of the extract did not impair co-ordination rather skeletal muscle activity was enhanced thus implying that the extract possessed the potential to enhance muscle activity and endurance ${ }^{36}$.

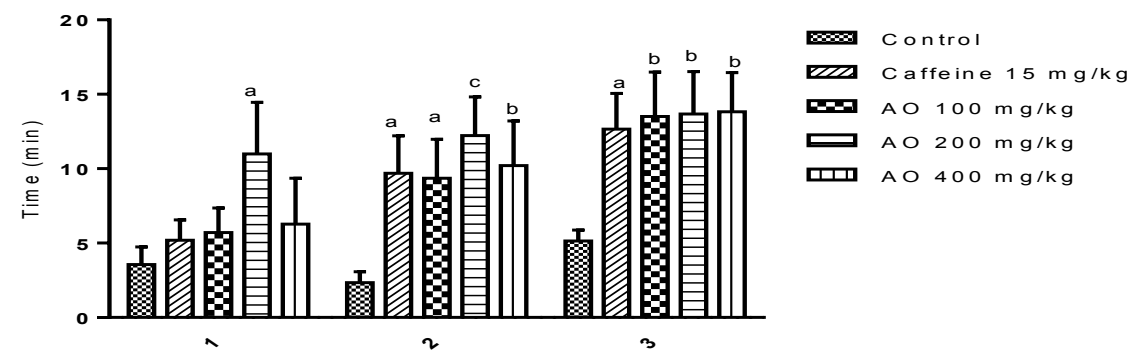

$\mathrm{DW}=$ Distilled water, $\mathrm{Caf}=$ Caffeine. Values are mean $\pm \operatorname{SEM}(\mathrm{n}=6) ;{ }^{\mathrm{a}} \mathrm{p}<0.05$ ${ }^{\mathrm{b}} \mathrm{p}<0.01$ significant vs control (Two-way ANOVA / Dunnet's post hoc test). 
Figure 3: Effect of Alysicarpus ovalifolius extract (AO) on Four-Limb Hanging test.

In the hypoxia endurance test the time spent by mice in hypoxic condition was not significantly increased by treatment of animals with extract of Alysicarpus ovalifolius or caffeine. The results obtained in the hypoxia endurance study showed that administration of caffeine was devoid of significant effects on oxygen utilization as the latency to onset of convulsion was not significantly $(\mathrm{p}<0.05)$ different from the untreated control group (Table 2). The extract treated animals did not show significant resistance and endurance to hypoxic conditions on comparison to untreated control group. This suggested that the extract may not produce observable influence on oxygen uptake during physical activity or physical stress ${ }^{37}$.

Table 2: Effect of aqueous extract of Alysicarpus ovalifolius (A0) on Hypoxia endurance test.

\begin{tabular}{lll}
\hline Treatment & Dose $(\mathbf{m g} / \mathbf{k g})$ & Latency to onset of convulsion $(\mathbf{m i n})$ \\
\hline Distilled water & $10 \mathrm{~m} / \mathrm{kg}$ & $35.00 \pm 1.16$ \\
Caffeine & 15 & $37.50 \pm 1.75$ \\
A. ovalifolius & 100 & $35.67 \pm 0.80$ \\
A. ovalifolius & 200 & $38.00 \pm 0.26$ \\
A. ovalifolius & 400 & $39.17 \pm 1.97$ \\
\hline
\end{tabular}

Results are presented as mean \pm SEM $(n=6)$. No significant difference between distilled water and treated groups.

Oxidation is necessary in several living organisms for the production of energy that is required for regular biological processes. Reactive oxygen species (ROS) are generated by contracting skeletal muscles during physical activity. Exhaustive exercise enhances the generation of these free radicals induced by increased oxygen consumption of active muscles. Exercise or acute, intense physical activity can cause oxidative stress which is an imbalance between ROS and the organism's antioxidant defense systems. Excessive ROS levels can lead to stress-related tissue damage, muscle fatigue and contractile dysfunction ${ }^{28,38,39}$. Also, when mice are exposed to a condition of hypoxia, a state of oxidative stress is induced ${ }^{25}$. Earlier studies have shown that administration of antioxidants inhibited the increase in blood levels of muscle injury markers and mitigated muscle fatigue ${ }^{40}$. Bashir et al (2018) had previously reported the antioxidant effects of Alysicarpus ovalifolius. It is therefore possible that the extract's antioxidant effects may be contributing in the reduction of exercise induced oxidative stress with subsequent delay in the onset of fatigue ${ }^{41}$.

In the diazepam induced sleep test, the results showed that administration of the plant extract caused delay in the onset of sleep and conversely decreased the duration of sleep when compared to control. However, the sleep duration increased with increasing dose of the extract (Table 3). 
Table 3: Effect of aqueous extract of Alysicarpus ovalifolius (A0) on diazepam induced sleep in mice.

\begin{tabular}{llll}
\hline Treatment & Dose $(\mathbf{m g} / \mathbf{k g})$ & Onset of sleep $(\mathbf{m i n})$ & Duration of sleep $(\mathbf{m i n})$ \\
\hline Distilled water & $10 \mathrm{ml} / \mathrm{kg}$ & $1.63 \pm 0.20$ & $245.70 \pm 22.72$ \\
Caffeine & 15 & $14.84 \pm 2.50^{\mathrm{d}}$ & $44.76 \pm 3.53^{\mathrm{d}}$ \\
A.ovalifolius & 100 & $4.74 \pm 0.98$ & $93.61 \pm 13.05^{\mathrm{c}}$ \\
A.ovalifolius & 200 & $3.61 \pm 0.36$ & $144.2 \pm 10.01^{\mathrm{a}}$ \\
A.ovalifolius & 400 & $4.49 \pm 0.10$ & $200.0 \pm 41.22$ \\
\hline
\end{tabular}

Results are presented as mean $\pm \operatorname{SEM}(n=7) .{ }^{a} p<0.05,{ }^{b} p<0.01,{ }^{c} p<0.001$, ${ }^{\mathrm{d}} \mathrm{p}<0.0001$ significant difference between distilled water and treated groups.

The results indicate that the extract may possess CNS stimulant effect as indicated by its ability to reduce the duration of diazepam-induced sleeping time at the doses tested ${ }^{42}$. Acute administration of psychoactive stimulants such as caffeine and amphetamine at low doses caused increased locomotion and enhanced physical activity. However, administration at high doses produced decreased motor activity ${ }^{43,44}$. Similar pattern was observed for AO extract as decreased performance at rotarod was recorded for the extract at $400 \mathrm{mg} / \mathrm{kg}$. The explanation for this observation of the extract cannot be explained within the scope of this study.

Analgesics are used by athletes in order to suppress pain and inflammation from injury thereby enhancing exercise performance and giving competitive advantage ${ }^{45}$. Our previous study reported the pain-relieving property of the phytoconstituents of $A$. ovalifolius ${ }^{46}$. This activity may also be playing a role to increase tolerance to pain thus prolonging the duration at a physical task.

It has been proposed that phytochemicals mediate their pharmacological actions by multiple complementary mechanisms of different constituents ${ }^{47}$. HPLC analysis detected the presence of caffeic acid, chlorogenic acid and rutin in this plant extract. These compounds have shown antioxidant activity ${ }^{48}$. Compounds such as caffeic and chlorogenic acids have demonstrated ergogenic actions in other experiments ${ }^{49}$. However, further studies will be necessary to determine the effects of the extract on biochemical markers of fatigue and muscle injury.

In conclusion, the extract of Alysicarpus ovalifolius mitigated the effects of exercise induced exhaustion thus indicating that the extract may possess constituents with the potentials to enhance physical endurance thereby delaying fatigue and improve performance. 


\section{CONFLICT OF INTEREST STATEMENT}

The authors declare no conflict of interest

\section{AUTHOR CONTRIBUTIONS}

LBJA conceptualization of the research, designed the study and was involved in laboratory work, collection, analysis and interpretation of data and wrote the manuscript. LKE was involved in laboratory work and data collection. SEO carried out the HPLC analysis and interpreted the spectra. AB did the critical analysis of the manuscript, contributed to the study design and is Head of the laboratory where this research work was carried out. All authors have read and approved the manuscript.

FUNDING: No funds were received for this project.

\section{ACKNOWLEDGEMENT}

The authors wish to acknowledge the technical assistance of Solomon. A. Fidelis. 


\section{REFERENCES}

1. Olajide A, Mansfield M, Olubankole O, \& Odoka O. Psychotropic drug prescription practice in psychiatric in-patients in Saskatchewan, Canada. J Neur Ment Health. 2016; 1(4): doi: 10.4172/2472-095X.100114.

2. Favrod-Coune T, \& Broers B. The Health effects of Psychostimulants: a literature review. Pharmaceuticals. 2010; 3, $2333-2361$.

3. Ilieva IP \& Farah MJ. Enhancement stimulants: perceived motivation and cognitive advantages Fron Neurosci. 2013; doi.org/10.3389/fnins.2013.00198

4. Morgan CJA, Noronha LA, Muetzelfeldt M, Fielding A \& Curran HV. Harms and benefits associated with psychoactive drugs: findings of an international survey of active drug users. $\mathrm{J}$ Herb Med. 2013; 27(6):497 - 506.

5. Mestry M, Bajaj A, Rane M. \& Lalan K. Herbal CNS stimulants. Int J Herb Med. 2016; 4(6): 109-116

6. Adamson TA, Ogunlesi AO, Morakinyo O, Akinhanmi AO, Onifade PO, Erinosho O, et, al. Descriptive National survey of Substance use in Nigeria. J Addict Res Ther. 2015; 6:3. Doi: 10.4172/2155-6105.1000234.

7. Eegunranti BA, Fatoye FO \& Morakinyo O. Stimulant use among secondary school students in Osogbo, Nigeria. Niger Postgrad Med J. 2009; 16(3):218-23.

8. Adayonfo EO. Pattern of stimulant use among Nigerian undergraduate students in Benin city. Nigeria. Ann. Biomed. Sci. 13(2):43 - 50.

9. Hildt E, Lieb K, Bagusat C \& Franke AG. Reflections on addiction in students using stimulants for neuroenhancement: A preliminary interview study. BioMed Res Int. doi. org/10.1155/2015/621075.

10. Adamu H, Ahmad MM, Mudi K, Dakani KM \& Bakare AT. Predictors of stimulants use among physicians in a Nigerian tertiary health institution in Sokoto, Northwest Nigeria. $\mathrm{J}$ Neurosci Behav Health. 10(2): 9-17.

11. Wood S, Sage JR, Shuman T \& Anagnostaras SG. Psychostimulants and cognition: a continuum of behavioural and cognitive activation. Pharmacol Rev. 66(1): 193 - 221.

12. Justo CC, Carneiro-de-Oliveira PE, DeLucia R, Aizenstein ML \& Planeta CS. Repeated exposure of adolescent rats to oral methylphenidate does not induce behavioural sensitization or cross-sensitization to nicotine. Braz J Med Biol Res. 2010; 43(7):651 - 656

13. Uddin S, Sufian MA, Hossain F, Kabir T, Islam T, Rahman M et al. Neuropsychological effects of caffeine: Is caffeine addictive? Psychol Psychother. 7:2. doi:10.1472/2161.1000295

14. Boys A, Marsden J \& Strang J. Understanding reasons for drug use amongst young people: a functional perspective. Health Educ Res. 6(4): 457 - 469.

15. Stangor A, \& Walinga J. Altering consciousness with psychoactive drugs. In: Introduction to Psychology 1st Canadian Edition. 2010; BCCampus Victoria. Canada.

16. Dukku, A. M. Emerging Perspectives on Drugs of Abuse: A Focus on Gadagi Consumption in Kano, Nigeria. Adv Psychol Neurosci. 2017; 2(2-1):7- 14.

17. Mannetje L. Alysicarpus ovalifolius (Schumach.) J. Leonard. (Internet) Record from PROTA4U. Oyen LPA \& Lemmens RHMJ (Editors). 2002; PROTA (Plant Resources of Tropical Africa/ Ressources vegetales de L'Afrique tropicale), Wageningen, Netherlands. Available at: http://www.prota4u.org/search.asp. 
18. Banwo OA. Phytochemical and some pharmacological studies of the aerial part of Alysicarpus ovalifolius Schumach \& Thonn Family: Fabaceae. 2013; Ahmadu Bello University Zaria (MSc thesis) 44.

19. Bashir M, Uzair M \& Ahmad B. Ethnobotanical, phytochemical and pharmacological aspects of genus Alysicarpus. Int J Pharm. 2018; 8(4):1-15

20. Ezenyi IC, Verma V, Singh S, Okhale SE \& Adzu B. Ethnopharmacology-aided antiplasmodial evaluation of six selected plants used for malaria treatment in Nigeria $J$ Ethnopharmacol. 2020; doi: 10.1016/j.jep.2020.112694.

21. Oh SL, Chang H, Kim HJ, Kim YA, Kim DS, Ho SH et al. Effect of HX108-CS supplementation on exercise capacity and lactate accumulation after high-intensity exercise. J Int Soc Sports Nutr. 2013; 10:21. doi:10.1186/1550-2783-10-21.

22. Xu Z. \& Shan Y. Anti-fatigue effects of polysaccharides extracted from Portulaca olarecea L. in mice. Indian J Biochem Biophys. 2014; 51: 321 - 325

23. Dickinson M, Flenniken A, Ji X. Teboul L, Wong MD, White JK. et al. High-throughput discovery of novel developmental phenotypes. Nature, 2016; 537, 508-514

24. Bonetto A, Andersson DC, \& Waning DL. Assessment of muscle mass and strength in mice. BoneKEy Reports 2015; 4, 732. doi:10.1038/bonekey.2015.101

25. Piato AL, Detanico BC, Linck VM, Herrmann AP, Nunes DS \& Elisabetsky E. Anti-stress effects of the "tonic" Ptychopetulatum olacoides (Marapuama) in mice. Phytomedicine 2010; $17: 248-253$

26. Rakotonirina AH, Ngo Bum E, Rakotonirina A \& Bopelet M. Sedative properties of the decoction of the rhizome of Cyperus articularis. Fitoterapia., 2001;72: 22 - 29.

27. Wang X, Qu Y, Zhang Y, Li S, Sun Y, Chen, Z, et. al. Antifatigue potential activity of Sarcodon imbricatus in acute excise-treated and chronic fatigue syndrome in mice via regulation of Nrf2mediated oxidative stress. Oxid Med Cell Longev. 2018; 9140896. doi: 10.1155/2018/9140896.

28. Jung K, Kim I-H \& Han D. Effect of medicinal plants extracts on forced swimming capacity in mice. J Ethnopharmacol. 2004; 93:75 - 81.

29. Kan NW, Ho, CS, Chiu YS, Huang WC, Chen PY, Tung YT, et.al. Effects of Resveratrol supplementation and exercise training on exercise performance in middle-aged mice. Molecules 2016; 21 (5):661Doi. 10.3390/molecles21050661

30. Li S \& Chen Z. Evaluation of antifatigue effects of 20(S)-Ginsenoside Rg3 in forced swimming in mice. Ind J Pharm Sci. 2018; 80(3):510 - 515.

31. Deacon RMJ. Measuring motor coordination in mice. J Vis Exp. 2013; 75:2609.

32. Rustay NR, Wahlsten D, \& Crabble JC. Influence of task parameters on rotarod performance and sensitivity to ethanol in mice. Behav Brain Res, 2003; 141: 237 - 249.

33. Amos S, Chindo B, Abbah J, Edmond I, Binda L, Adzu B, et al. Neuropharmacological effects of the aqueous extract of Nauclea latifolia root bark in rats and mice. $J$ Ethnopharmacol. 2005; 97: $53-57$.

34. Garige BSR, Keshetti S \& Vattikuti UMR. Invivo study on depressant effects and muscle coordination glauca stem methanol extract. Pharmacogn Res. 2016; 8(4):219 - 225.

35. Guo SS, Gao XF, Gu YR, Wan ZX, Lu AM, Qin ZH, et al. Preservation of cognitive function by Lepidium meyenii (maca) is associated with improvement of mitochondrial activity and upregulation of autophagy-related proteins in middle-aged mouse cortex. Evid-Based Complementary Altern Med. 2016; doi: 10.1155/2016/4394261. 
36. Toda K, Hitoe S, Takeda S \& Shimoda H. Black ginger extract increases physical fitness performance and muscular endurance by improving inflammation and energy metabolism. Heliyon. 2016; doi.org/10.1016/j.heliyon. 2016.eoo115.

37. Guoquan J \& Yueying L. Study of safflower on blood lactate concentration and exercise function of mice after exercise. Afr J Biotechnol. 2011; 19(45): 9148 - 9152.

38. Belviranli M. \& Gokbel H. Acute exercise induced oxidative stress and antioxidant changes. Eur J Gen Med. 2006; 3(3): 126-131.

39. He F, Li J, Liu Z, Chuang CC, Yang W \& Zuo L. Redox Mechanism of Reactive Oxygen Species in Exercise. Front Physiol. 2016; 7:486. doi:10.3389/fphys.2016.00486

40. Kawamura T \& Muraoka I. Exercise induced oxidative stress and the effects of antioxidant intake from a physiological viewpoint. Antioxidants, 2018; 7:119. doi:10.3390/antiox7090119.

41. Vina J, Gomez-Cabrera MC, Lloret A, Marquez R, Minana JB, Pallardo FV et. al. Free radicals in exhaustive physical exercise mechanism of production and protection by antioxidants. Life. 2002; 50:271 - 277.

42. Owolabi OJ, Amaechina FC \& Eledan AB. Central nervous system stimulant effect of the ethanolic extract of Kigelia Africana. J Med Plant Res. 2008; 2(2): 20 - 23.

43. Yates JW, Meiji JTA, Sullivan JR, Richtand NM \& Yu L. Neurosci Lett. 2007; 427(1):66- 70.

44. Almosawi S, Mahdi S, Baksh H, Qareeballa A, Falamarzi F, Assaleh B et. al. Acute administration of caffeine: The effect on motor coordination, higher brain cognitive functions and the social behavior of BLC57 mice. Behav Sci. (Basel). 2018; 8(8):65. doi:10.3390/bs8080065.

45. Lundberg TR \& Howatson G. . Analgesic and anti-inflammatory drugs in sports: Implications for exercise performance and training adaptations. Scand J Med Sci Sports. 2018; 28(11): 2252 - 2262. doi.org/10.1111/sms.13275.

46. John-Africa LB, Danborno AM, Tikinade MG \& Kayinu N. . Anti-nociceptive effects of the hydro-ethanolic extract of Alysicarpus ovalifolius in rodents. J Med Plant Res. 2020; 14(5): $195-201$.

47. Carmona F \& Pereira AMS. Herbal medicines: old and new concepts, truths and misunderstandings. Rev Bras Farmacogn. 2013; 23(2):379 - 385 .

48. Kaurinovic B \& Vastag D. Flavonoids and phenolc acids as potential natural antioxidants. In Antioxidants. E Shalaby, Ed. IntechOpen. 2018; Doi 10.5772/intechopen.83731. pp 1-14.

49. Sellami M, Slimeni O, Pokrywka A, Kuvacic G, Hayes LD, Milic M et. al. Herbal medicine for sports: a review. J Int Soc Sports Nutr. 2018; 15,14. doi.org/10.1186/s12970-018-0218-y. 
The manuscript entitled "Irritant Contact Dermatitis Activity of some xanthones from Swertia petiolata D.Don" with the doi number 10.23893/1307-2080.APS.05921 is not published because "Ethical Approval Statement" and "Ethical Committee Number" is not provided. 